\title{
ФАКТОРИ РИЗИКУ ТА ПРОГНОЗУВАННЯ ПЕРЕБІГУ ХІРУРГІЧНОГО ЛІКУВАННЯ У ХВОРИХ НА МІСЦЕВИЙ ПЕРИТОНІТ
}

\author{
І. К. Чурпій \\ (churpiy_igor@yahoo.com) \\ Івано-Франківський національний медичний університет
}

Досліджена можливість кількісної оцінки фракторів ризику виникнення ускладнень при лікуванні місцевого перитоніту. Виділено 46 груп ознак, що мають значення при прогнозуванні перебігу місцевого перитоніту. Пропонована схема визначення ризику клінічного перебігу місцевого перитоніту дозволяє кількісно оцінити тяжкість вихідного стану хворих й у більшості випадків правильно спрогнозувати результати лікування захворювання.

Ключові слова: перитоніт, фактори ризику, прогнозування ускладнень.

\section{ФАКТОРЫ РИСКА И ПОГНОЗИРОВАНИЕ ТЕЧЕНИЯ ХИРУРГИЧЕСКОГО ЛЕЧЕНИЯ БОЛЬНЫХ С МЕСТНЫМ ПЕРИТОНИТОМ}

И. К. Чурпий

\author{
Ивано-Франковский национальный медицинский университет
}

\begin{abstract}
Исследована возможность количественной оценки факторов риска, которые могут привести к возникновению осложнений при местном перитоните. Выделено 46 наиболее важных клинических признаков, имеющих значение в прогнозировании течения местного перитонита.
\end{abstract}

Ключевые слова: перитонит, фракторы риска, прогнозирование осложнений.

\section{RISK FACTORS AND PROGNOSIS OF SURGICAL TREATMENT COURSE IN PATIENTS WITH PERITONITIS}

I. K. Churpiy

\author{
ivano-Frankivsk State Medical University
}

The possibility of quantifying the risk factors of complications in the treatment of peritonitis was investigated. There are allocated 46 clinical features that are relevant to the prognosis of peritonitis.

Key words: peritonitis, factors risk, prognosis complication.

Вступ. Лікування перитоніту залишається складною та невирішеною проблемою абдомінальної хірургії, як і багато років назад [1]. Про незадовільні результати лікування перитоніту свідчить летальність 25-30\%, що утримується протягом останніх десятиріч та змушує хірургів шукати нові шляхи подолання даної проблеми [2].

В останні роки для покращення результатів лікування перитонітів почали використовувати інформаційні технології. Це може бути вкрай актуально у діагностично складних і важко передбачуваних клінічних ситуаціях, у яких від лікаря вимагаються не тільки глибокі знання та практичні навики, а й вміння проаналізувати дані, скласти алгоритм дій та спрогнозувати результат [3, 4].

(C) І. К. Чурпій, 2011
Метою нашого дослідження було визначення прогностичної значимості найважливіших клінічних ознак як факторів ризику для прогнозування перебігу та результату лікування місцевого перитоніту.

Основна частина.

Здійснений ретроспективний аналіз 200 медичних карт стаціонарних хворих з місцевим перитонітом різної етіології. Всі обстеження проводилися при надходженні в клініку (до початку лікування) та після інтраопераційної санації черевної порожнини.

Структура патології була наступною: гострий флегмонозний апендицит (ГФА) - 114 випадків, гострий гангренозний апендицит (ГГА) - 37, гострий перфоративний апендицит (I ПА) - 11, гострий калькульо- 
зний холецистит (ГКХ) - 26, сальпінгіт - 2, защемлена грижа - 6, апоплексія - 4 .

Із 200 хворих померло 8, що підтверджувало наявні фактори ризику при лікуванні місцевого перитоніту.

Всім хворим здійснювалося загальноклінічне обстеження: збір скарг, анамнезу хвороби, фізикальні, клініколабораторні обстеження та їх інтегральна оцінка.

Основою вивчення передопераційного, інтра- та післяопераційного стану хворих, а також прогнозування перебігу захворювання становили "фактори ризику". Їх визначали шляхом оцінки значення клінічних показників в визначенні ймовірності виникнення ускладнень під час лікування хворих.

Відповідно, на першому етапі дослідження була створена карта автоматизованого обліку хворого з перитонітом, яка включала дані клініко-лабораторних обстежень, відомості анамнезу і операційні знахідки.
Кількісні значення прогностичної значимості клінічної інформації здійснювали за допомогою методики М. М. Амосова та співавторів [5].

Всього аналізували 139 ознак перитоніту, що включали дані анамнезу, клінічного обстеження, лабораторних, спеціальних й інструментальних методів обстеження.

На підставі дослідження й аналізу 16 груп клінічних ознак та їх градацій (шаблонів), що вивчалися для виявлення факторів ризику перебігу перитоніту (табл.1) було відібрано 46 найбільш значимих факторів для прогнозування результату захворювання (табл. 2). Фактори представлені з позитивними та негативними значеннями, тобто вони можуть мати позитивне і негативне значення для прогнозу. В дослідженні припускається, що прогноз буде визначатися сумою балів, що характеризують важливість сим-

Таблиця 1. Групи клінічних ознак та їх градації (шаблони), що вивчалися для виявлення факторів ризику перебігу перитоніту.

\begin{tabular}{|c|c|c|c|c|c|c|}
\hline \multirow{3}{*}{$\begin{array}{l}\text { № } \\
\text { п/п }\end{array}$} & \multirow{3}{*}{ Фактор } & \multirow{3}{*}{$\begin{array}{c}\text { Кількість } \\
\text { спостережень }\end{array}$} & \multicolumn{3}{|c|}{ Результат } & \multirow{3}{*}{$\begin{array}{l}\text { Значен- } \\
\text { ня, бали }\end{array}$} \\
\hline & & & \multirow{2}{*}{$\begin{array}{c}\text { добрий } \\
\text { осіб }\end{array}$} & \multicolumn{2}{|c|}{ несприятливий } & \\
\hline & & & & осіб & $\%$ & \\
\hline 1. & Чоловіча стать & 130 & 128 & 2 & 1,6 & $-0,7$ \\
\hline 2. & Жіноча стать & 150 & 144 & 6 & 4 & 0,67 \\
\hline 3. & $\begin{array}{l}\text { Вік: } \\
18-20 \\
21-40 \\
41-50 \\
51-60 \\
61-75 \\
76-90 \\
>90\end{array}$ & $\begin{array}{c}58 \\
106 \\
45 \\
36 \\
24 \\
8 \\
3\end{array}$ & $\begin{array}{c}58 \\
106 \\
45 \\
35 \\
21 \\
6 \\
1\end{array}$ & $\begin{array}{l}0 \\
0 \\
0 \\
1 \\
3 \\
2 \\
2\end{array}$ & $\begin{array}{c}0 \\
0 \\
0 \\
2,8 \\
12,5 \\
25 \\
66,7\end{array}$ & $\begin{array}{c}0 \\
0 \\
0 \\
-0,2 \\
1,94 \\
2,97 \\
4,96\end{array}$ \\
\hline 4. & $\begin{array}{l}\text { Поширеність перитоніту: } \\
\text { Місцевий }\end{array}$ & 280 & 272 & 8 & 2,18 & 0 \\
\hline 5. & $\begin{array}{l}\text { Термін госпіталізації: } \\
\text { До } 6 \text { год. } \\
\text { 6-12 год. } \\
\text { 12-24 год. } \\
\text { 24-48 год. } \\
48-72 \text { год. } \\
\text { >72 год. }\end{array}$ & $\begin{array}{c}11 \\
105 \\
98 \\
35 \\
17 \\
14\end{array}$ & $\begin{array}{c}11 \\
105 \\
98 \\
38 \\
13 \\
10\end{array}$ & $\begin{array}{l}0 \\
0 \\
0 \\
0 \\
4 \\
4\end{array}$ & $\begin{array}{c}0 \\
0 \\
0 \\
0 \\
23,5 \\
28,6\end{array}$ & $\begin{array}{c}0 \\
0 \\
0 \\
0 \\
2,8 \\
3,2 \\
\end{array}$ \\
\hline 6. & $\begin{array}{l}\text { Місцевість проживання: } \\
\text { Місто } \\
\text { Село } \\
\end{array}$ & $\begin{array}{c}210 \\
70 \\
\end{array}$ & $\begin{array}{c}204 \\
68\end{array}$ & $\begin{array}{l}6 \\
2\end{array}$ & $\begin{array}{l}2,8 \\
2,8\end{array}$ & $\begin{array}{l}-0,15 \\
-0,15\end{array}$ \\
\hline 7. & $\begin{array}{l}\text { Перенесені захворювання, } \\
\text { шкідливі звички: } \\
\text { Інсульт } \\
\text { Інфаркт міокарда } \\
\text { Гепатит } \\
\text { Перенесені операції на ОЧП } \\
\text { Травми ОЧП } \\
\text { Алергічні захворювання } \\
\text { Вживання алкоголю } \\
\text { Тютюнопаління }\end{array}$ & $\begin{array}{c}7 \\
11 \\
14 \\
45 \\
10 \\
18 \\
6 \\
50\end{array}$ & $\begin{array}{c}5 \\
9 \\
12 \\
41 \\
10 \\
16 \\
6 \\
47\end{array}$ & $\begin{array}{l}2 \\
2 \\
2 \\
4 \\
0 \\
2 \\
0 \\
3\end{array}$ & $\begin{array}{c}28,6 \\
18,2 \\
14,3 \\
8,9 \\
0 \\
11,1 \\
0 \\
6\end{array}$ & $\begin{array}{c}3,2 \\
2,4 \\
2,11 \\
1,5 \\
0 \\
1,81 \\
0 \\
1,1\end{array}$ \\
\hline
\end{tabular}


Продовження табл. 1

\begin{tabular}{|c|c|c|c|c|c|c|}
\hline \multirow{3}{*}{$\begin{array}{l}\text { № } \\
\text { п/п }\end{array}$} & \multirow{3}{*}{ Фактор } & \multirow{3}{*}{$\begin{array}{c}\text { Кількість } \\
\text { спостережень }\end{array}$} & \multicolumn{3}{|c|}{ Результат } & \multirow{3}{*}{$\begin{array}{l}\text { Значен- } \\
\text { ня, бали }\end{array}$} \\
\hline & & & \multirow{2}{*}{$\begin{array}{l}\text { добрий } \\
\text { осіб } \\
\end{array}$} & \multicolumn{2}{|c|}{ несприятливий } & \\
\hline & & & & осіб & $\%$ & \\
\hline \multirow[t]{6}{*}{8.} & Етіологічний чинник: & 128 & 128 & 0 & 0 & 0 \\
\hline & Гострий гангренозний апендицит & 67 & 66 & 1 & 1,5 & $-0,71$ \\
\hline & Гострий перфоративний апендицит & 21 & 20 & 1 & 4,8 & 0,84 \\
\hline & Гострий калькульозний холецистит & 58 & 53 & 5 & 8,6 & 1,51 \\
\hline & Защемлена грижа & 2 & 1 & 1 & 50 & 4,32 \\
\hline & Апоплексія яєчників & 4 & 4 & 0 & 0 & 0 \\
\hline \multirow[t]{8}{*}{9.} & Характер ексудату: & & & & & \\
\hline & Серозний & 78 & 78 & 0 & 0 & 0 \\
\hline & Серозно-фібринозний & 139 & 139 & 0 & 0 & 0 \\
\hline & Гнійний & 14 & 14 & 0 & 0 & 0 \\
\hline & Гнійно-фібринозний & 25 & 24 & 1 & 4 & 0,77 \\
\hline & Жовчний & 14 & 9 & 5 & 35,7 & 3,57 \\
\hline & Геморагічний & 4 & 4 & 0 & 0 & 0 \\
\hline & Каловий & 6 & 4 & 2 & 33,3 & 3,44 \\
\hline \multirow[t]{17}{*}{10.} & Супутня патологія: & & & & & \\
\hline & IXC, кардіосклероз & 78 & 70 & 8 & 10,2 & 1,69 \\
\hline & Порушення серцевого ритму & 15 & 9 & 6 & 40 & 3,8 \\
\hline & Гіпертонічна хвороба II-III ст. & 85 & 77 & 8 & 9,4 & 1,6 \\
\hline & Цукровий діабет I тип & 6 & 5 & 1 & 16,7 & 2,32 \\
\hline & Цукровий діабет II тип & 18 & 15 & 3 & 16,7 & 2,32 \\
\hline & Ожиріння II-IV ст. & 74 & 68 & 6 & 8,1 & 1,43 \\
\hline & Анемія & 4 & 3 & 1 & 25 & 2,94 \\
\hline & Захворювання бронхів та легень & 37 & 32 & 5 & 13,5 & 2,03 \\
\hline & Захворювання печінки & 17 & 14 & 3 & 17,6 & 2,39 \\
\hline & Захворювання нирок & 15 & 11 & 4 & 26,7 & 3,05 \\
\hline & Ревматична хвороба серця & 16 & 14 & 2 & 12,5 & 1,94 \\
\hline & СНІД & 1 & 1 & 0 & 0 & 0 \\
\hline & Злукова хвороба очеревини & 20 & 16 & 4 & 20 & 2,58 \\
\hline & Варикозна хвороба нижніх кінцівок & 94 & 86 & 8 & 8,5 & 1,48 \\
\hline & Захворювання підшлункової залози & 28 & 24 & 4 & 14,3 & 2,11 \\
\hline & Виразкова хвороба шлунка і ДПК & 7 & 5 & 2 & 28,6 & 3,16 \\
\hline \multirow[t]{4}{*}{11.} & Фази розвитку: & & & & & \\
\hline & Реактивна & 181 & 181 & 0 & 0 & 0 \\
\hline & Токсична & 90 & 90 & 0 & 0 & 0 \\
\hline & Термінальна & 9 & 1 & 8 & 88,9 & 5,78 \\
\hline \multirow[t]{6}{*}{12.} & Об'см оперативних втручань: & & & & & \\
\hline & Апендектомія & 219 & 217 & 2 & 0,9 & $-0,87$ \\
\hline & Грижовисікання і резекція & $\begin{array}{l}2 \\
4\end{array}$ & 1 & 1 & 50 & $\begin{array}{l}4,28 \\
293\end{array}$ \\
\hline & $\begin{array}{l}\text { кишечника } \\
\text { Холешистектомія }\end{array}$ & $\begin{array}{c}4 \\
54\end{array}$ & $\begin{array}{c}3 \\
50\end{array}$ & $\begin{array}{l}1 \\
4\end{array}$ & $\begin{array}{l}25 \\
7.4\end{array}$ & $\begin{array}{l}2,93 \\
1,32\end{array}$ \\
\hline & Лапароскопічна холецистектомія & 1 & 1 & 0 & 0 & 0 \\
\hline & $\begin{array}{l}\text { Клиновидна резекція яєчника } \\
\text { Лапароскопічна діагностика }\end{array}$ & 3 & 3 & 0 & 0 & 0 \\
\hline \multirow[t]{7}{*}{13.} & Ускладненя зі сторони рани: & & & & & \\
\hline & Інфільтрат & 21 & 21 & $\begin{array}{l}0 \\
0\end{array}$ & $\begin{array}{l}0 \\
0\end{array}$ & $\begin{array}{l}0 \\
0\end{array}$ \\
\hline & Нагноєння & 10 & 9 & 1 & 10 & 1,67 \\
\hline & Гематома & 10 & 10 & 0 & 0 & 0 \\
\hline & $\begin{array}{l}\text { Розходження швів апоневрозу } \\
\text { (евентерапія) }\end{array}$ & 3 & 2 & 1 & 33,3 & 3,44 \\
\hline & Розходження країв рани & & & & & \\
\hline & (евентерація) & 3 & 3 & 0 & 0 & 0 \\
\hline
\end{tabular}


Продовження табл. 1

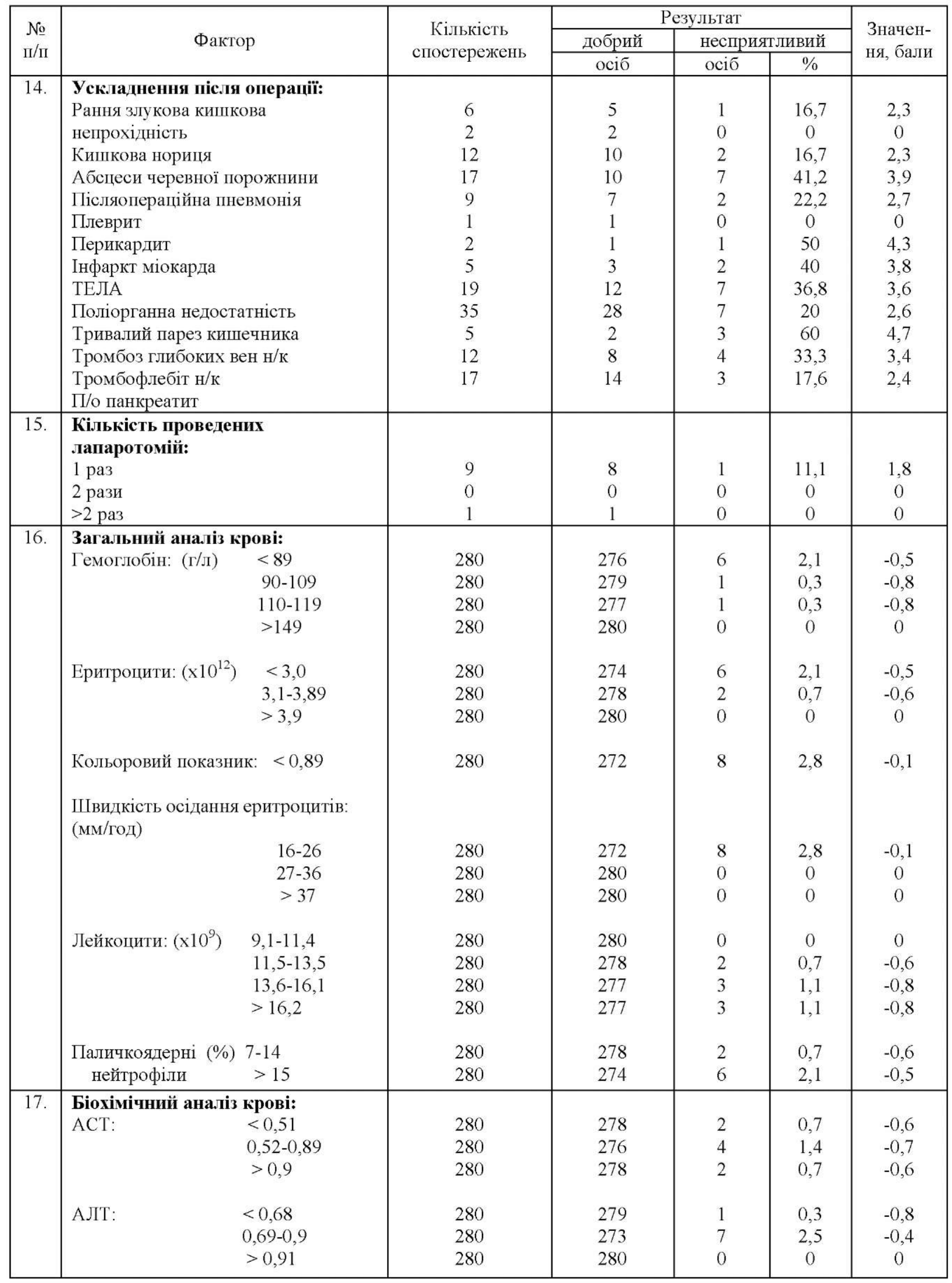


Продовження табл. 1

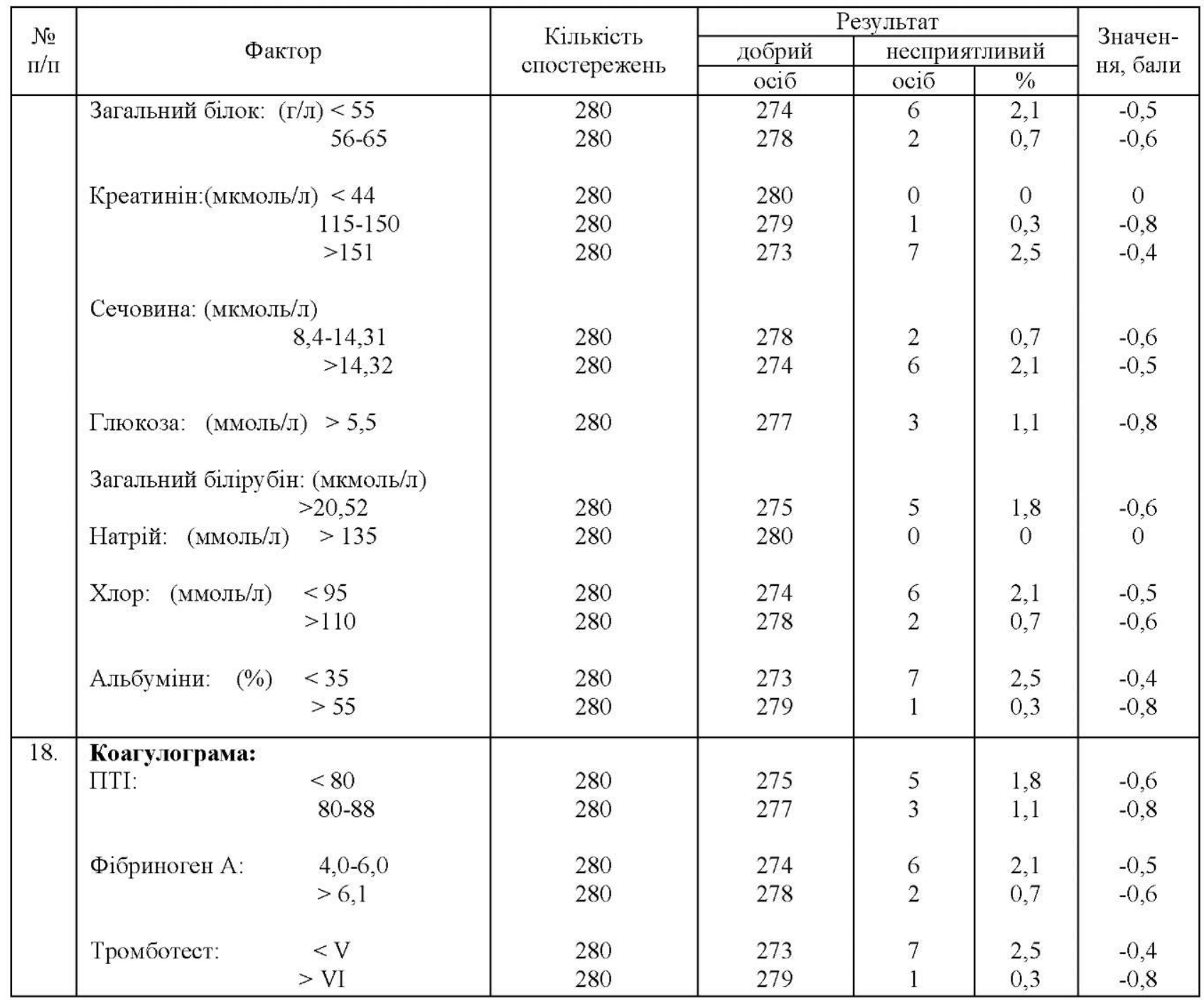

Примітка: Середня частота несприятливих результатів в усіх випадках складала 2,86 \%.

Таблиця 2. Прогностична значимість факторів, що визначають ускладнення перебігу перитоніту.

\begin{tabular}{|l|c|}
\hline \multicolumn{1}{|c|}{ Фактори ризику погіршення при місцевому перитоніті } & Бали \\
\hline Жіноча стать & 0,67 \\
\hline Вік 61 - 75 років & 1,94 \\
\hline 76 - 90 років & 2,97 \\
\hline$>90$ років & 4,96 \\
\hline Госпіталізація 48 години & 2,8 \\
\hline$>72$ годин & 3,2 \\
\hline Перенесені захворювання: інсульт & 3,2 \\
\hline Інфаркт міокарда & 2,4 \\
\hline Гепатит & 2,1 \\
\hline Алергія & 1,8 \\
\hline Гострий калькульозний холецистит & 1,5 \\
\hline Защемлена грижа & 4,3 \\
\hline Характер ексудату: жовчний & 3,6 \\
\hline Характер ексудату: каловий & 3,4 \\
\hline Супутня патологія: порушення ритму & 3,8 \\
\hline Цукровий діабет І тип & 2,3 \\
\hline
\end{tabular}


Продовження табл. 2

\begin{tabular}{|c|c|}
\hline Фактори ризику погіршення при місцевому перитоніті & Бали \\
\hline Цукровий діабет II тип & 2,3 \\
\hline Анемія & 2,9 \\
\hline Захворювання печінки & 2,4 \\
\hline Захворювання нирок & 3,05 \\
\hline Злукова хвороба очеревини & 2,6 \\
\hline Захворювання підшлункової залози & 2,1 \\
\hline Термінальна фаза перитоніту & 5,8 \\
\hline Грижовисікання з резекцією кишечника & 4,3 \\
\hline Холецистектомія & 2,9 \\
\hline Нагноєння п/о рани & 1,7 \\
\hline Евентрація & 3,4 \\
\hline Рання кишкова непрохідність & 2,3 \\
\hline Абсцеси черевної порожнини & 2,3 \\
\hline Післяопераційна пневмонія & 3,9 \\
\hline Плеврит & 2,7 \\
\hline Інфаркт міокарда & 4,3 \\
\hline ТЕЛА & 3,8 \\
\hline Поліорганна недостатність & 3,6 \\
\hline Тромбоз н/к & 4,7 \\
\hline Тромбофлебіт н/к & 3,4 \\
\hline П/о панкреатит & 2,4 \\
\hline Гемоглобін: $\quad$ < 89 (г/л) & $-0,5$ \\
\hline Еритроцити: (х10 ) <3,0 & $-0,5$ \\
\hline Швидкість осідання еритроцитів: (мм/год) 16-26 & $-0,1$ \\
\hline Паличкоядерні: (\%) > 15 & $-0,5$ \\
\hline Загальний білок: (г/л) > 55 & $-0,5$ \\
\hline Креатинін:(мкмоль/л) >151 & $-0,4$ \\
\hline Альбуміни: $\quad(\%) \quad<35$ & $-0,4$ \\
\hline Коагулограма: ПТІ < 80 & $-0,6$ \\
\hline Фібриноген А: $\quad 4,0-6,0$ & $-0,5$ \\
\hline
\end{tabular}

птомів, виявлених у хворих. Первісне число прогностичних ознак було більшим, однак перевірка кореляційних зв'язків дозволила скоротити їхню кількість за рахунок виключення менш значимих.

При аналізі факторів погіршення при місцевому перитоніті найбільш вагомими виявилися жіноча стать, вік 76 - 90 років, що складає 2,9 - 3 бали. У віці понад 90 років різко зростає ймовірність погіршення прогнозу, тому прогностичне значення цього показника сягає майже 5 балів. Час до госпіталізації у стаціонар відіграє важливу роль. Так, якщо він не перевищує 48 годин, то складає 2,8 бала. Подовження терміну більше 72 годин значно збільшує негативний вплив на перебіг.

3 перенесених захворювань на першому місці стоїть інсульт - 3,2 бала, далі інфаркт міокарда - 2,4 та гепатит - 2,1 бала. Найбільш тяжким захворюванням $\epsilon$ защемлена грижа - 4,3 та гострий калькульозний холецистит - 1,5 бала. При порівнянні характеру ексудату в прогнозуванні найбільш важливим виявився жовчний (3,6 ум. од.) та каловий $(3,4$ ум. од.). Суп- ровідна патологія також впливає на перебіг місцевого перитоніту. Важливими є порушення серцевого ритму ${ }^{\wedge}$-критерій дорівнює 3,8), анемія (2,9 бала), захворювання нирок $(3,05)$, Інша патологія рівнозначно впливає на перебіг. Однакове значення має цукровий діабет I та II типів - по 2,3 бала. Термінальна фаза перитоніту є найтяжчою в перебігу та прогнозуванні несприятливого наслідку (відповідне значення Іжритерію дорівнює 5,8). Найбільш травматичними оперативними втручаннями виявилися грижовисікання з резекцією тонкого кишечника (4,3 бала) та відкрита холецистектомія (2,9 бала). При аналізі післяопераційних ускладнень прогностично несприятливими факторами зі сторони рани визнані евентрація (3,4 бала) та нагноєння (1,7 бала). Аналіз інших систем та органів свідчить, що інфаркт міокарда, тромбоз нижніх кінцівок, розвиток поліорганної недостатності знаходяться майже в рівній залежності і однаково впливають на перебіг.

Аналіз лабораторних показників в меншій мірі відображає перебіг перитоніту. Про це свідчить те, 
що всі прогностичні значення показників $є$ від'ємними. Найбільш характерними виявилися ШОЕ (1>критерій дорівнює -0,1), креатинін > 151 мкмоль/л, альбумін $<35 \%$.

Більшість отриманих показників мають високу інформаційно-клінічну цінність, корелюють 3 даними літератури й відрізняються тільки тим, що кількісно характеризують тяжкість захворювання.

Виділені та сформовані фактори ризику, наведені в цій роботі, будуть сприяти правильному ухваленню рішення при виборі обсягу консервативного та оперативного лікування даної категорії хворих.

Висновки. 1. Провідними факторами ризику перебігу та результату місцевого перитоніту є жіноча стать, вік 76 - 90 років і більше, час до госпіталізації

\footnotetext{
Лтература

1. Сепсис и полиорганная недостаточность / Саенко В. Ф., Десятерик В. И., Перцева Т. А. [и др.] - Кривой Рог: Минерал, 2005. - $466 \mathrm{c.}$

2. Оптимізація програми комплексного лікування хворих 3 розповсюдженим гнійним перитонітом / Годлевський А. I., Кацал В. А., Саволюк С. І., Годлевська Н. А. // Матеріали XXI з'їзду хірургів України. - Запоріжжя, 2005. - Т 2. - С. 453 -454.

3. Гусев А. В. Обзор медицинских информационных систем на отечественном рынке в 2005 году / А. В. Гусев,
}

більше 72 годин, наявність в анамнезі інсульту, порушення серцевого ритму, наявність жовчного та калового ексудату, термінальна фаза, грижовисікання 3 резекцією тонкої кишки, вони призводять до розвитку таких ускладнень як евентрація, нагноєння післяопераційної рани, післяопераційні пневмонії, інфаркт міокарда, тромбоз нижніх кінцівок. У прогнозуванні результату комплексного лікування перитоніту варто також ураховувати деякі біохімічні показники.

2. На основі визначення факторів ризику пропонується створити схему визначення ризику клінічного перебігу місцевого перитоніту. Вона дозволить кількісно оцінити тяжкість вихідного стану хворих й у більшості випадків правильно спрогнозувати результати лікування захворювання.

Ф. А. Романов, И. П. Дуданов // Медицинский академический журнал. - 2005. - Т. 5, №> 3. - С. 72 - 84.

4. Інформаційні технології в хірургії / О. П. Мінцер, В. 3. Москаленко, С. В. Веселий. - Кн. 3 в 10 книгах "Інформаційні технології в охороні здоров'я і практичній медицині". - К. : "Вища школа", 2004. - 423 с.

5. Амосов Н. М. Факторы риска протезирования митрального клапана / Н. М. Амосов, Л. Н. Сидоренко, О. П. Минцер // Грудная хирургия. - 1975. - №9 3. - С. 9-16. 